\title{
High Threshold for Induction of the Stress Response in Motor Neurons Is Associated with Failure to Activate HSF1
}

\author{
Zarah Batulan, ${ }^{1}$ Gayle A. Shinder, ${ }^{1}$ Sandra Minotti, ${ }^{1}$ Bei Ping He, ${ }^{2}$ Mohammad M. Doroudchi, ${ }^{1}$ Josephine Nalbantoglu, \\ Michael J. Strong, ${ }^{2,3}$ and Heather D. Durham ${ }^{1}$ \\ ${ }^{1}$ Montreal Neurological Institute and Department of Neurology and Neurosurgery, McGill University, Montreal, Quebec, Canada H3A 2B4, \\ ${ }^{2}$ Neurodegeneration Research Group, The John P. Robarts Research Institute, and ${ }^{3}$ Department of Clinical Neurological Sciences, The University of Western \\ Ontario, London, Ontario, Canada N6A 5A5
}

Heat shock protein 70 (Hsp70) protects cultured motor neurons from the toxic effects of mutations in $\mathrm{Cu} / \mathrm{Zn}$-superoxide dismutase (SOD-1), which is responsible for a familial form of the disease, amyotrophic lateral sclerosis (ALS). Here, the endogenous heat shock response of motor neurons was investigated to determine whether a high threshold for activating this protective mechanism contributes to their vulnerability to stresses associated with ALS. When heat shocked, cultured motor neurons failed to express $\mathrm{Hsp} 70$ or transactivate a green fluorescent protein reporter gene driven by the $\mathrm{Hsp} 70$ promoter, although $\mathrm{Hsp} 70$ was induced in glial cells. No increase in $\mathrm{Hsp} 70$ occurred in motor neurons after exposure to excitotoxic glutamate or expression of mutant SOD-1 with a glycine $\rightarrow$ alanine substitution at residue 93 (G93A), nor was Hsp70 increased in spinal cords of G93A SOD-1 transgenic mice or sporadic or familial ALS patients. In contrast, strong Hsp70 induction occurred in motor neurons with expression of a constitutively active form of heat shock transcription factor (HSF)-1 or when proteasome activity was sufficiently inhibited to induce accumulation of an alternative transcription factor HSF2. These results indicate that the high threshold for induction of the stress response in motor neurons stems from an impaired ability to activate the main heat shock-stress sensor, HSF1.

Key words: ALS; amyotrophic lateral sclerosis; heat shock; HSF1; HSF2; Hsp70; motor neuron; proteasome inhibition

\section{Introduction}

The heat shock response is an evolutionarily conserved, cytoprotective mechanism mediated by stress-induced transcription of genes encoding heat shock-stress proteins (HSP) (for review, see Morimoto et al., 1997). Families of stress-induced HSPs and constitutively expressed heat shock cognate proteins (HSC) facilitate nascent protein folding, refolding, or degradation of abnormally folded proteins, protein targeting, and cellular signaling (Gabai et al., 1997; Morimoto and Santoro, 1998; Meriin et al., 1999). Eukaryotic expression of HSPs is mediated by binding and activation of heat shock transcription factors (HSFs) to heat shock elements (HSEs) on HSP promoters (Morimoto and Santoro, 1998). Environmental and physiological stresses activate transcription of HSP genes in mammals primarily through HSF1 (Morimoto, 1998), whereas HSF2 participates in heat shock gene transactivation developmentally (Min et al., 2000) and in the presence of proteasomal inhibitors (Mathew et al., 1998).

HSPs can protect neural cells from various stresses including hyperthermia, ischemia, oxidative stress, and excitotoxicity (Lo-

Received March 3, 2003; revised April 14, 2003; accepted April 21, 2003.

This research was supported by the Canadian Institutes for Health Research, the ALS Society of Canada, and the ALS Association. We thank Dr. R. I. Morimoto for helpful discussion, the HSF2 antibody, and HSE-GFP reporter construct, Dr. R. Voellmy for the HSF1 constructs, Dr. S. David for the MAC-1 antibody, Emily Tam for assistance with MG132 experiments, and Dr. P. McPherson for assistance with GFP imaging.

Correspondence should be addressed to Dr. Heather D. Durham, Montreal Neurological Institute, 3801 University Street, Montreal, Quebec, Canada H3A 2B4. E-mail: heather.durham@mcgill.ca.

Copyright $\odot 2003$ Society for Neuroscience $\quad$ 0270-6474/03/235789-10\$15.00/0 wenstein et al., 1991; Rordorf et al., 1991; Uney et al., 1993; Yenari et al., 1998). Findings from our laboratory extended the neuroprotective role of the major stress-inducible heat shock protein 70 isoform (Hsp70) to a culture model of amyotrophic lateral sclerosis (ALS), a neurodegenerative disease characterized by loss of motor neurons in the brain and spinal cord. Approximately $20 \%$ of familial ALS (FALS) cases are caused by autosomal dominant mutations in $\mathrm{Cu} / \mathrm{Zn}$-superoxide dismutase ( $S O D-1)$ (Rosen et al., 1993).

Toxicity of mutant SOD-1 is attributable to a gain of function rather than a loss of the primary enzymatic function, dismutation of superoxide to hydrogen peroxide. One proposed mechanism of disease pathogenesis is that mutations in SOD-1 confer structural changes in the protein, resulting in altered solubility and aggregation (Deng et al., 1993; Bruijn et al., 1997; Durham et al., 1997; Johnston et al., 2000; Shinder et al., 2001). Consistent with the cellular response to accumulation and aggregation of abnormal proteins, cell lines surviving stable overexpression of mutant SOD-1 exhibit upregulation of the HSPs, Hsp70, Hsp25, and $\alpha \mathrm{B}$-crystallin and an increase in chaperoning activity. Expression of mutant SOD-1 in motor neurons of dissociated murine spinal cord cultures resulted in aggregation of this protein into inclusions and loss of viability (Durham et al., 1997). Both manifestations of mutant SOD-1 toxicity were delayed by gene transfer of Hsp70 (Bruening et al., 1999), suggesting that an insufficient stress response in motor neurons increases their vulnerability to toxicity. The present study investigated the endogenous heat 
shock response in motor neurons, as monitored by induction of Hsp70 and other HSPs after exposure to hyperthermia and two stresses associated with ALS: glutamate excitotoxicity and expression of SOD-1 with glycine $\rightarrow$ alanine substitution at residue 93 (G93A SOD-1). The data show a high threshold for induction of the stress response in motor neurons attributable to the lack of activation of the major stress-sensing transcription factor HSF1.

\section{Materials and Methods}

Spinal cord cultures. Primary cultures of dissociated spinal cord and dorsal root ganglia (DRG) were prepared from embryonic day 13 CD1 mice and cultured on poly-D-lysine-coated glass coverslips as described previously (Roy et al., 1998). Cultures were used $4-8$ weeks after plating and large motor neurons were distinguished from other cell types as described previously (Roy et al., 1998).

Transgenic mice. The following lines were maintained in our animal facilities: B6SJL-TgN(SOD1-G93A)1Gur (expressing G93A mutant human SOD-1; hemizygotes become paralyzed in one or more limbs at $\sim 4$ months of age), B6.Cg-TgN(SOD1-G93A) ${ }^{\mathrm{dl}} 1 \mathrm{Gur}$ (hemizygotes develop clinical disease at $\sim 8$ months), and B6.Cg-TgN(SOD1)2Gur [expressing wild-type (wt) human SOD-1] (Dal Canto and Gurney, 1994, 1995; Chiu et al., 1995). Nontransgenic littermates were used as controls. Genotyping was performed by PCR analysis of DNA isolated from ear tissue according to protocols provided by the Jackson Laboratory (Bar Harbor, $\mathrm{ME})$. End-stage disease was defined as paralysis in one or both hind limbs. To obtain spinal cords, mice were killed by intraperitoneal injection of ketamine-xylazine (Ketaset, Wyeth-Ayerst, Montreal, Quebec, Canada; Rompun, Chemagro Limited, Etobicoke, Ontario, Canada). All procedures were within the guidelines of the Canadian Council of Animal Care and the Animal Care Committee of McGill University.

Human spinal cord sections. Archival paraffin-embedded cervical spinal cord sections were studied from control (two cases; neurologically normal), sporadic ALS (three cases), and autosomal dominant FALS (three cases, one SOD-1 A4V mutation and two without linkage to SOD-1).

Exposure of spinal cord DRG cultures to thermal and excitotoxic stress. For heat shock, spinal cord cultures were placed in minimum essential medium enriched with $5 \mathrm{gm}$ of glucose without sodium bicarbonate, $\mathrm{pH}$ 7.2 , heat shocked in a temperature controlled water bath, and recovered for variable periods at $37^{\circ} \mathrm{C}-5 \% \mathrm{CO}_{2}$ before analysis of HSP expression. To induce excitotoxic stress, an appropriate volume of a $100 \mathrm{~mm}$ stock of glutamic acid (Sigma, Oakville, ON) was added.

Microinjection of plasmid vectors into cultured motor neurons. To study the effect of G93A mutant and wild-type human SOD-1 on Hsp70 induction in motor neurons, cDNAs were subcloned into pCEP4 and microinjected into motor neuron nuclei at $200 \mu \mathrm{g} / \mathrm{ml}$ in Tris-EDTA as described previously (Durham et al., 1997). pcDNA3.1 plasmids encoding the following forms of human HSF1 were provided courtesy of Dr. R. Voellmy (University of Miami, Miami, FL) and injected at $0.5 \mu \mathrm{g} / \mathrm{ml}$; $\mathrm{HSF} 1^{\text {wt }}$, constitutively activated HSF $1\left(\mathrm{HSF} 1^{(+)}\right.$or BH-S; resulting from deletion of amino acids 202-316, which regulates transactivational competence of HSF1), and nonactivatable HSF1 (HSF1 ${ }^{(-)}$or AV-ST; resulting from deletion of amino acids 453-523, which spans the transcriptional activation domain) (Zuo et al., 1995). Plasmid containing the green fluorescent protein (GFP) gene under the control of the inducible human Hsp70 promoter [pEGFP (enhanced GFP)-HSE-GFP; courtesy of Dr. R. I. Morimoto, Northwestern University, Evanston, IL] was injected at $0.1 \mu \mathrm{g} / \mathrm{ml}$, and $70 \mathrm{kDa}$ dextran fluorescein or dextran tetramethylrhodamine (TMR) $(20 \mu \mathrm{g} / \mu \mathrm{l}$; Molecular Probes, Eugene, OR) was included to mark injected cells. After microinjection, coverslips were transferred to $5 \% \mathrm{CO}_{2}$-equilibrated culture medium supplemented with $0.75 \%$ gentamycin and placed in a $37^{\circ} \mathrm{C}-5 \% \mathrm{CO}_{2}$ incubator. Cultures were either immunolabeled with antibody to Hsp70 or imaged for GFP expression in real time using MetaVue (GFP exposure time, 2 sec; TMR exposure time, $0.625 \mathrm{sec}$; Universal Imaging Corporation, Downington, PA).

Treatment with proteasomal inhibitors. Spinal cord cultures were transferred to $\mathrm{CO}_{2}$-equilibrated medium containing either MG132 (at final concentrations of $0.1,1,2.5$, or $5 \mu \mathrm{M}$; Peptide Institute, Minoh, Japan) or DMSO carrier and were incubated overnight.

Antibodies. Primary antibodies were used against the following: SOD-1 (clone SD-G6, 1:300, Sigma; SOD-100, 1:100, Stressgen Biotechnologies, Victoria, BC), Hsp70 (SPA-810 for inducible Hsp70, 1:1000 for blots, 1:100 for immunolabeling of cultures and mouse tissue sections, 1:500 for human tissue sections, Stressgen Biotechnologies; W27 for both inducible and constitutive Hsp70, 1:100 Santa Cruz Biotechnology, Santa Cruz, CA), Hsc70 (K19, 1:1000 for blots; Santa Cruz Biotechnology), Hsp25 (SPA-801 for rodent Hsp25 with no cross reaction to Hsp27 primate isoform, 1:500/1000 for blots; Stressgen Biotechnologies), Hsp27 (M20, recognizes primate Hsp27 and rodent Hsp25, 1:100 for immunolabeling of cultures, 1:1000 for sections; Santa Cruz Biotechnology), $\alpha$ B-crystallin (SPA-222 and SPA-223, 1:1000 for blots, 1:100 for immunolabeling; Stressgen Biotechnologies), ubiquitin (1:1000; Dako, Carpinteria, CA), HSF1 (SPA-950, 1:100; Stressgen Biotechnologies), HSF2 (1:10; courtesy of Dr. R. I. Morimoto, Northwestern University, Evanston, IL), actin (clone C4, 1:1000; ICN Biomedicals, Cleveland, $\mathrm{OH}$ ), glial fibrillary acidic protein (GFAP) (Z0334, 1:100 for immunolabeling of cultures, 1:2000 for sections; Dako), neurofilament heavy chain (N-4142, 1:100; Sigma), nitrotyrosine (1:100; Upstate Biotechnology, Lake Placid, NY), MAC-1 (courtesy of Dr. Sam David, McGill University, Montreal, Canada). For epifluorescence microscopy, cultures were labeled with appropriate secondary antibodies (Alexa-fluor 1:100; Molecular Probes). For Vectastain ABC detection systems, biotin-conjugated secondary antibodies were used (1:100; Vector Laboratories, Burlingame, CA). For blots, secondary antibodies conjugated to horseradish peroxidase (HRP) were used (mouse IgG and rat IgG, 1:3000, Jackson ImmunoResearch, West Grove, PA; rabbit IgG and goat IgG, 1:5000-1: 10000, Dako).

Sample preparation for Western blotting. Spinal cord cultures were harvested in lysis buffer containing the following: $20 \mathrm{~mm}$ HEPES, pH 7.5, 100 $\mathrm{mm} \mathrm{KCl}, 5 \%$ glycerol, $0.1 \%$ Nonidet P-40, $0.1 \mathrm{~mm}$ phenylmethylsulfonyl fluoride (PMSF). After $30 \mathrm{~min}$ of incubation on ice, cell lysates were centrifuged at $12,700 \times \mathrm{g}$ for $15 \mathrm{~min}$ at $4^{\circ} \mathrm{C}$. Lumbar spinal cords from mice were homogenized in $500 \mu \mathrm{l}$ of the following lysis buffer: PBS, $\mathrm{pH}$ 8.0, containing $0.5 \%$ Nonidet-P40, $0.2 \%$ digitonin, and $0.23 \mathrm{~mm}$ PMSF. Cellular debris was pelleted by centrifugation at $15,400 \times g$ for $15 \mathrm{~min}$ at $4^{\circ} \mathrm{C}$. Supernatant fractions of culture or spinal cord homogenates were collected and protein concentrations were determined using the DC Protein Assay (Bio-Rad, Mississauga, Canada).

Western blotting. For spinal cord culture samples, $10 \mu \mathrm{g}$ of protein were mixed with an equal volume of sample buffer (130 mm Tris, $\mathrm{pH} 6.8$, $20 \%$ glycerol, $2 \%$ SDS, $10 \% \beta$-mercaptoethanol, $0.08 \%$ bromophenol blue), boiled for $2 \mathrm{~min}$, electrophoresed on 10\% SDS-polyacrylamide gels, and transferred to Bio-Rad trans-blot transfer medium. Membranes were blocked for $1 \mathrm{hr}$ with 5\% milk in TBST (50 mm Tris- $\mathrm{HCl}, \mathrm{pH} 7.5$, $150 \mathrm{~mm} \mathrm{NaCl}, 0.1 \%$ Tween 20) and then incubated for $2 \mathrm{hr}$ at room temperature (RT) or overnight at $4^{\circ} \mathrm{C}$ with primary antibody diluted in TBST containing $5 \%$ milk and $0.02 \% \mathrm{NaN}_{3}$. After washing in TBST, blots were incubated in HRP-conjugated secondary antibody-5\% milk-TBST for $2 \mathrm{hr}$ at RT. Protein bands were visualized on $\mathrm{x}$-ray film after incubation of the blots in the Renaissance Western blot chemiluminescence reagent (NEN, Boston, MA). Films were scanned using Microtek (Torrance, CA) Scan Wizard. Expression of HSPs was normalized to actin by quantitating band density on films using ImageQuant software (Amersham Biosciences, Baie D’Urfe, Quebec, Canada).

For lumbar spinal cord homogenates, $10 \mu \mathrm{g}$ of protein were mixed with an equal volume of sample buffer, boiled for $5 \mathrm{~min}$, electrophoresed on $12.5 \%$ SDS-polyacrylamide gels, and transferred to nitrocellulose. Membranes were blocked overnight at $4^{\circ} \mathrm{C}$ in TBST-milk. Incubations with primary and secondary antibodies were $1 \mathrm{hr}$ at RT. Protein bands were detected as described for culture samples. Hsp25 and $\alpha \mathrm{B}$-crystallin levels were normalized to tubulin by quantitating bands using NIH Image or ImageQuant software.

Immunocytochemistry. Immunocytochemistry using fluorescent dyeconjugated secondary antibodies was performed as described previously (Roy et al., 1998). Biotin-conjugated secondary antibodies were visual- 


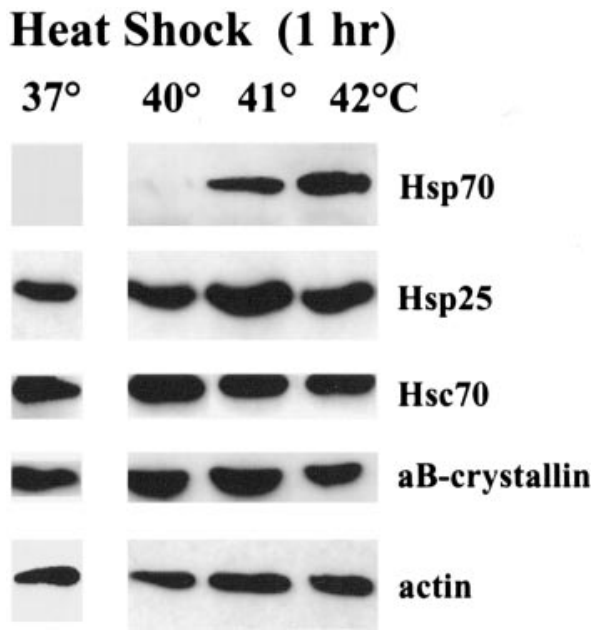

Figure 1. Heat shock induces $\mathrm{Hsp} 70$ in spinal cord cultures. Spinal cord cultures were subjected to increasing heat shock temperatures $\left(40-42^{\circ} \mathrm{C}\right)$ for $1 \mathrm{hr}$, followed by $2 \mathrm{hr}$ recovery at $37^{\circ}$. Western blots were probed with antibodies to HSPs [Hsp70 (SPA-810), Hsp25 (SPA-801), $\mathrm{Hsc70}$ (K19), and $\alpha \mathrm{B}$-crystallin (SPA-222)] and actin as loading control. Blots shown are representative of three different experiments. Only Hsp70 was upregulated.

ized using the Vectastain ABC peroxidase kit (Vector Laboratories) and $0.05 \%$ DAB.

Immunohistochemistry. Lumbar spinal cords from transgenic mice were placed in Histo-Prep frozen tissue-embedding media (Fisher Scientific, Ottawa, Canada) and frozen in isopentane. Twenty micrometer cross sections were mounted onto glass slides and fixed in 3\% paraformaldehyde for $30 \mathrm{~min}$, permeabilized in $0.5 \%$ Nonidet-P40-PBS for 5 min, fixed in 3\% paraformaldehyde for $2 \mathrm{~min}$, and blocked for $3 \mathrm{hr}$ at RT. To prevent nonspecific labeling with mouse monoclonal primary antibodies, $\mathrm{F}_{\mathrm{AB}}$ fragment anti-mouse IgG $\mathrm{H}+\mathrm{L}$ (Jackson ImmunoResearch) was added for $30 \mathrm{~min}$. Endogenous peroxidase activity was quenched by 5 min incubation with $2 \% \mathrm{H}_{2} \mathrm{O}_{2}$. Primary antibodies were incubated overnight and detected using biotinylated secondary antibodies $(1 \mathrm{hr}$ at RT), Vectastain ABC peroxidase system, and 0.05\% DAB. Sections were dehydrated in ethanol, dipped in xylene, and mounted in Permount (Fisher Scientific).

Human ALS spinal cord sections were deparaffinized using routine techniques. Antigen retrieval was performed at $\mathrm{pH} 10.0$, and slides were incubated with $3 \% \mathrm{H}_{2} \mathrm{O}_{2}$ for $5 \mathrm{~min}, 5 \%$ BSA for $20 \mathrm{~min}$, and $0.1 \%$ trypsin-0.1 M PBS, pH 7.2, for $15 \mathrm{~min}$ at $37^{\circ} \mathrm{C}$. Sections were labeled with either SPA-810 monoclonal antibody recognizing Hsp70 (1:500) or a goat antibody recognizing Hsp27 (M20; 1:1,000) overnight at $4^{\circ} \mathrm{C}$ and detected using HRP-conjugated secondary antibodies and the Elite Vectastain ABC peroxidase system (Vector Laboratories) with $0.05 \%$ DAB.

\section{Results}

Heat shock-induced Hsp70 expression in glial cells but not motor neurons

Because induction of Hsp70 is a well characterized feature of the cellular response to hyperthermia, Hsp70 expression was used as the primary marker to investigate the heat shock-stress response in spinal cord cells. Primary spinal cord cultures were exposed for $1 \mathrm{hr}$ to increasing temperatures $\left(40-42^{\circ} \mathrm{C}\right)$ and then incubated for $2 \mathrm{hr}$ at $37^{\circ} \mathrm{C}$ to allow for protein synthesis. Initially, HSP expression was examined by Western blotting to screen for thermally induced changes (Fig. 1). Inducible Hsp70 was minimal to nondetectable in cultures maintained at the $37^{\circ} \mathrm{C}$ control temperature, but increasing levels were observed in cultures exposed to temperatures above $40^{\circ} \mathrm{C}$. When normalized to levels of actin, an approximate twofold increase in $\mathrm{Hsp} 70$ occurred at $42^{\circ} \mathrm{C}$ compared with $41^{\circ} \mathrm{C}$. Expression of other HSPs, Hsp25, Hsc70, and $\alpha \mathrm{B}$-crystallin was evaluated by immunoblotting, but no consis-
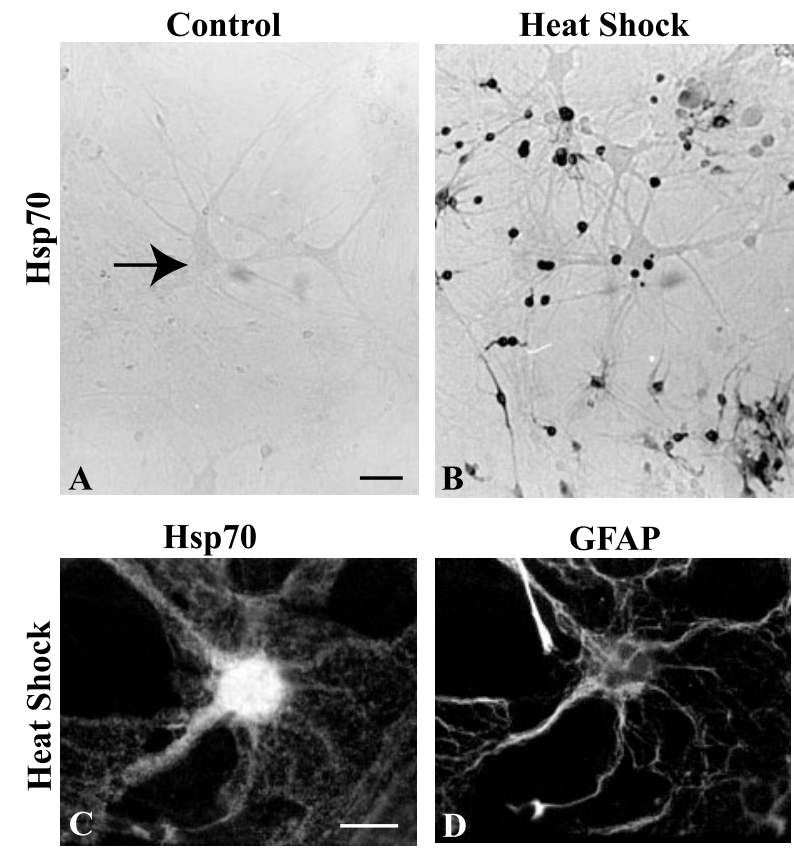

Figure 2. Glial cells, but not motor neurons, upregulate $H$ sp70 after heat shock. $A-D$, Spinal cord cultures were subjected to $37^{\circ} \mathrm{C}$ control temperature $(A)$ or $42^{\circ} \mathrm{C}$ heat shock $(B-D)$ for $1 \mathrm{hr}$, followed by $2 \mathrm{hr}$ recovery at $37^{\circ} \mathrm{C}$. Hsp70 induction was assessed by immunocytochemistry using biotin-conjugated secondary antibodies and DAB as substrate $(A, B)$ or by fluorescenceconjugated secondary antibodies ( $C$. Heat-shocked spinal cord cultures were also double labeled with antibodies against GFAP $(D)$ to verify that glial cells induced Hsp70. The arrow in $A$ points to a motor neuron. Scale bars: $A, B, 50 \mu \mathrm{m} ; C, D, 20 \mu \mathrm{m}$.

tent increases were observed after heat shock at $40-42^{\circ} \mathrm{C}$ relative to levels at the control temperature of $37^{\circ} \mathrm{C}$.

To determine the cell types in spinal cord cultures that upregulated Hsp70 after heat shock, immunocytochemistry was performed (Fig. 2). After heat shock for $1 \mathrm{hr}$ at $42^{\circ} \mathrm{C}$ and $2 \mathrm{hr}$ of recovery at $37^{\circ} \mathrm{C}$, numerous non-neuronal cells expressed Hsp70, whereas motor neurons did not (Fig. $2 \mathrm{~B}$ ). Double labeling of cultures with antibodies to Hsp70 and the high molecular weight neurofilament protein confirmed the lack of Hsp70 in large neurons with motor neuron morphology as well as DRG and other neurons in the culture at this heat shock condition (our unpublished data). Double labeling with antibody against the astrocytic marker GFAP confirmed that astrocytes expressed Hsp70 after heat shock (Fig. 2C,D).

The absence of Hsp70 induction under these conditions of heat shock could be attributable to sufficient levels of constitutively expressed HSPs, such as Hsc70 or Hsp25, thereby obviating induction of the $H s p 70$ gene. Thus, different paradigms of heat shock were examined, including higher temperatures $\left(43^{\circ} \mathrm{C}\right.$ and $44^{\circ} \mathrm{C}$ ), increasing durations of hyperthermia (up to $8 \mathrm{hr}$ ), and prolonged recovery times (up to $6 \mathrm{hr}$ ). Some of these extreme heat shock conditions caused motor neuron death; however, surviving motor neurons still failed to induce Hsp70, although expression was detected in other neurons, including DRG neurons, under these conditions (our unpublished data). Together, these results indicate that motor neurons have either a weak or nonexistent stress response after exposure to thermal stress.

\section{Glutamate excitotoxicity did not induce Hsp70 in motor neurons}

Glutamate excitotoxicity has been implicated in the pathogenesis of ALS (for review, see Cleveland and Rothstein, 2001) both 


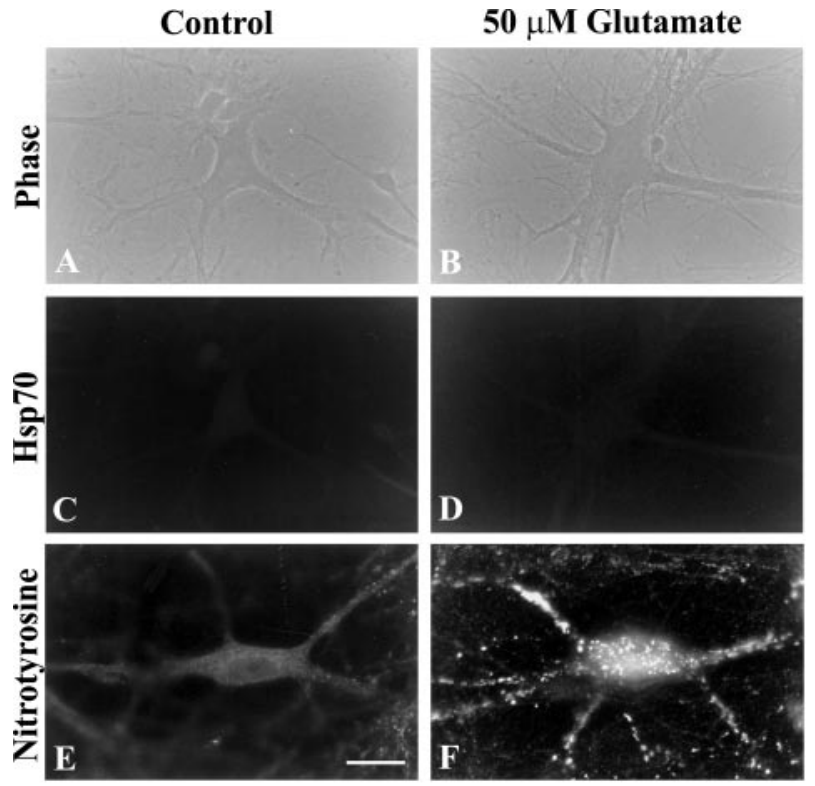

Figure 3. Motor neurons failed to express $\mathrm{Hsp} 70$ in response to glutamate. $A-F$, Spinal cord cultures were treated with $50 \mu \mathrm{m}$ glutamic acid $(B, D, F)$ or vehicle $(A, C, E)$ for 30 min and then assessed for Hsp70 induction by immunocytochemistry (SPA-810). Nitrotyrosine labeling demonstrated that glutamate treatment had an effect on motor neurons $(E, F)$. Scale bar, $20 \mu \mathrm{m}$

through loss of the astrocytic glutamate transporter GLT-1 and consequent exposures to higher levels of glutamate (Rothstein et al., 1995; Cleveland and Rothstein, 2001) and through increased sensitivity to normally nonlethal levels of glutamate (Roy et al., 1998; Ludolph et al., 2000). In previous studies, neuronal cells were protected from glutamate excitotoxicity by a preconditioning mild heat stress, which induced HSPs (Lowenstein et al., 1991; Rordorf et al., 1991). However, the involvement of Hsp70 specifically has depended on the experimental model. Glutamate induced Hsp70 in neurons of hippocampal slices (Sato and Matsuki, 2002) but not in cerebellar granule neurons (Lowenstein et al., 1991). Overexpression of Hsp70 failed to protect cultured cortical or hippocampal neurons from glutamate excitotoxicity (Snider and Choi, 1996; Fink et al., 1997); yet, knockdown of Hsp70 using antisense oligonucleotides sensitized neurons of hippocampal slices to glutamate (Sato and Matsuki, 2002). To determine whether glutamate can affect the heat shock response of motor neurons, spinal cord cultures were exposed to excitotoxic levels of glutamate. In preliminary experiments, motor neuron death began $30 \mathrm{~min}$ after the addition of $50 \mu \mathrm{M}$ glutamate with $\sim 40 \%$ cell loss occurring $4 \mathrm{hr}$ later. Spinal cord cultures were treated for $30 \mathrm{~min}$ with 25 or $50 \mu \mathrm{M}$ glutamate and analyzed immediately or after a $2 \mathrm{hr}$ recovery by immunocytochemistry. No induction of Hsp70 was observed in motor neurons under these conditions (Fig. 3C,D). However, the absence of Hsp70 expression was not because of unresponsiveness of motor neurons to glutamate, because strong anti-nitrotyrosine labeling, an indicator of glutamate toxicity (for review, see Doroudchi et al., 2001), was observed (Fig. 3E,F). Thus, like heat shock, glutamate excitotoxic stress failed to upregulate Hsp70 in motor neurons. By Western blot analysis, glutamate also failed to induce Hsp70 or alter total levels of Hsp25, Hsc70, and $\alpha \mathrm{B}$-crystallin in spinal cord cultures (our unpublished data).
Table 1. Expression of mutant SOD-1 fails to induce Hsp70 in cultured motor neurons

\begin{tabular}{lll}
\hline & \multicolumn{2}{l}{$\begin{array}{l}\text { Percentage of motor neurons expressing Hsp70 } \\
\text { (mean } \pm \text { SD) }\end{array}$} \\
\cline { 2 - 3 } Expression construct & Day 3 & Day 5 \\
\hline pCEP4 & 0 & $3.3 \pm 5.7$ \\
wild-type SOD-1 & $2.3 \pm 4.0$ & $1.7 \pm 2.9$ \\
G93A SOD-1 & $6.2 \pm 4.3$ & $5.5 \pm 4.9$ \\
\hline
\end{tabular}

Motor neurons in dissociated spinal cord cultures were microinjected with dextran-fluorescein marker and pCEP4 empty vector, $\mathrm{pCEP} 4 /$ wild-type SOD-1, or pCEP4/G93A SOD-1. Cultures were double labeled with antibodies against human SOD-1 (SOD-100) and Hsp70 (SPA-810 or W27) and viewed using epifluorescence microscopy. Values indicate mean percentage of motor neurons immunopositive for both human SOD-1 and Hsp70 at 3 and $5 \mathrm{~d}$ after microinjection; average of results from three cultures, with 15- 40 human SOD-positive neurons per culture.

\section{Expression of G93A SOD-1 in motor neurons did not induce Hsp70}

To determine whether expression of the disease-causing mutant protein G93A SOD-1 results in Hsp70 induction in cultured motor neurons, plasmid expression vectors encoding wildtype or G93A SOD-1 were microinjected into the nuclei of motor neurons in primary spinal cord cultures. In this model, motor neuron loss begins $\sim 3 \mathrm{~d}$ after microinjection of G93A SOD- 1 expression plasmid and reaches $\sim 50 \%$ at day five (Durham et al., 1997; Roy et al., 1998). At these times, Hsp70 expression in motor neurons expressing wildtype or G93A SOD-1 was compared by double-labeling cultures with antibodies against Hsp70 and human SOD-1. Hsp70 was detected at low levels in a small percentage of cells, but there was no significant difference among those coexpressing wildtype and G93A SOD-1 (Table 1).

Hsp70 expression in motor neurons was also investigated in B6SJL-TgN(SOD1-G93A)1Gur transgenic mice. Similar to findings in the FALS culture model, Hsp70 was not detected in motor neurons in lumbar spinal cord sections by immunohistochemistry at 80,92 , or $115 \mathrm{~d}$ of age (Fig. $4 A-C$ ). Obvious loss of motor neurons in the ventral horn was apparent between 92 and $115 \mathrm{~d}$ as documented in previous studies of these mice (Dal Canto and Gurney, 1994, 1995; Chiu et al., 1995; Hall et al., 1998; Kong and $\mathrm{Xu}, 1998)$. Rarely, an immunoreactive background cell was observed, indicating that the antibody could recognize Hsp70 under these experimental conditions.

\section{Reactive astrocytes in spinal cords of mutant SOD-1} transgenic mice upregulated Hsp25

By Western blotting, a significant increase in Hsp 25 was observed in lumbar spinal cord homogenates from symptomatic G93A SOD-1 transgenic mice relative to age-matched nontransgenic and wild-type SOD-1 transgenic animals (Fig. 5A). The level of Hsp 25 was also greater in symptomatic, relative to nonsymptomatic, G93A SOD-1 littermates killed at $115 \mathrm{~d}$ of age. Labeling of adjacent spinal cord sections with antibodies against Hsp25 and GFAP determined that Hsp25 was localized to reactive astrocytes (Fig. 4G-L). This pattern of Hsp25 labeling was distinct from the microglial marker MAC-1, which also increased with disease progression (Fig. 4M-O). The number of Hsp25-expressing astrocytes and intensity of labeling increased between 80 and $115 \mathrm{~d}$ of age, paralleling total levels of Hsp25 in spinal cord homogenates (Fig. 5A) and the time course of motor neuron loss, microglial infiltration, and clinical progression of disease (vide supra). At early stages, astrogliosis was restricted to the ventral gray matter (preclinical phase) and increased progressively until the end stage of disease ( $\sim 4$ months of age). At the end stage, Hsp25 and GFAP-expressing astrocytes were prominent throughout the gray matter. Neither astrocytosis nor microglial activation were 

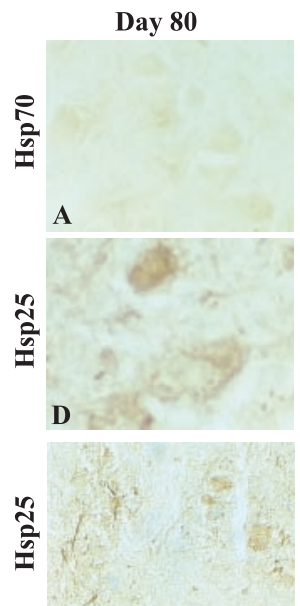

G
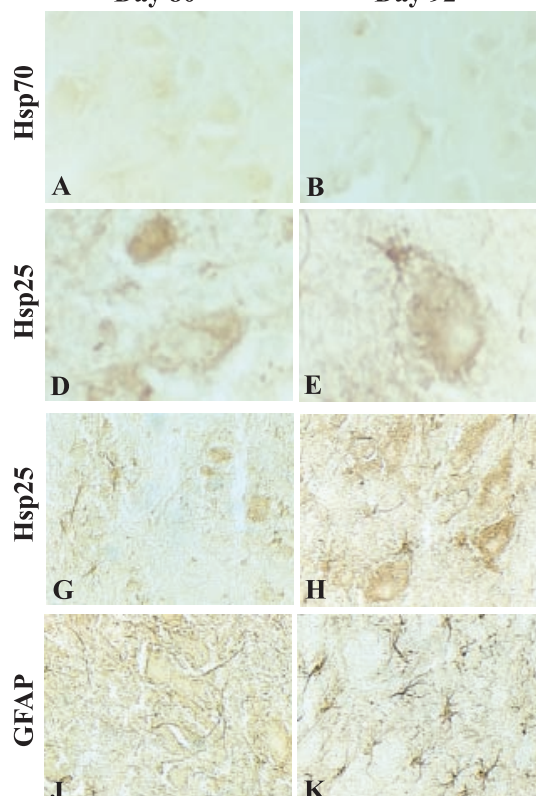

Day 92

Day 115
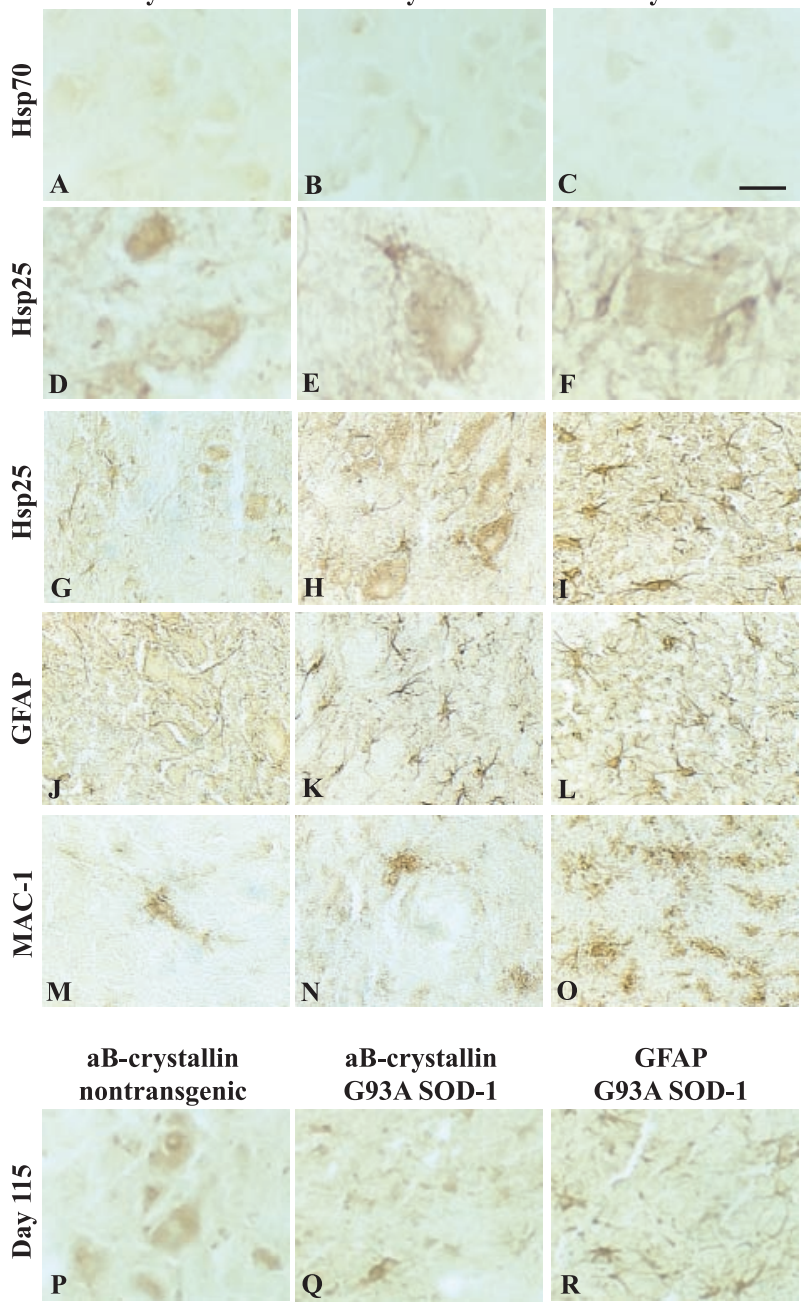

Figure 4. Expression of HSPs in lumbar spinal cord of G93A mutant SOD-1 transgenic mice. The $20 \mu \mathrm{m}$ sections of lumbar spinal cord from 80, 92, and 115-d-old mice were labeled with antibodies to Hsp70 (SPA-810), Hsp25 (M20; recognizes primate Hsp27 and rodent Hsp25), GFAP, MAC-1, or $\alpha \mathrm{B}$-crystallin. No induction of $\mathrm{Hsp} 70$ was observed ( $A-C$ ). Motor neurons constitutively expressed Hsp25 (D-F), but no qualitative changes were noted with disease progression. There was a progressive increase in $\mathrm{Hsp} 25$ expressing astrocytes with age $(G-I)$. Motor neurons of 115-d-old nontransgenic mice constitutively expressed $\alpha \mathrm{B}$-crystallin (P). In lumbar cord from 115-d-old symptomatic G93A SOD-1 transgenics, $\alpha$ B-crystallin was detected in some but not all reactive astrocytes $(Q, R)$. Reactive astrocytes and microglia were identified by expression of GFAP $(J, K, L, R)$ and $M A C-1(M-0)$ labeling of adjacent sections, respectively. Scale bars: $A-C, G-R, 40 \mu \mathrm{m} ; D-F, 15.4 \mu \mathrm{m}$.

observed in spinal cords of nontransgenic littermates or wildtype SOD-1 transgenic mice (our unpublished data). Constitutive expression of Hsp25 was observed in motor neurons as reported previously (Plumier et al., 1997). However, no qualitative difference in expression was noted by immunohistochemistry in motor neurons of G93A SOD-1 mice, either with disease progression (Fig. $4 D-F$ ) or in comparison with motor neurons of agematched wild-type SOD-1 mice or nontransgenic littermates (our unpublished data).

$\alpha \mathrm{B}$-crystallin was detected by immunohistochemistry in motor neurons as well as unidentified cells throughout the neuropil but appeared similar in all lines of transgenic mice (Fig. 4P,Q). In the spinal cord from symptomatic G93A SOD-1 mice, a subpopulation of reactive astrocytes expressed $\alpha \mathrm{B}$-crystallin (Fig. $4 Q, R)$. However, this was at a much lesser extent than that seen with Hsp25 and was not sufficient to be reflected on Western
A

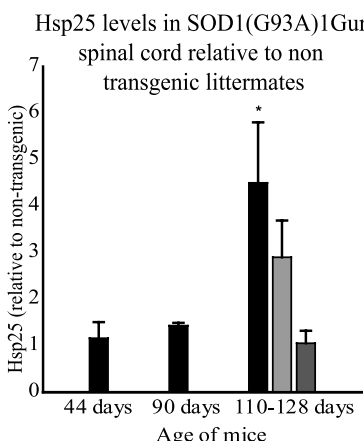

B

$\alpha \mathrm{B}$-crystallin in SOD1(G93A)1Gur

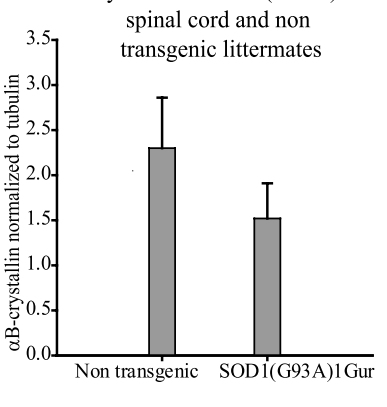

SOD-1(G93A)1 Gur symptomatic SOD-1(G93A) 1Gur non-symptomatic (SOD-1)2Gu

Figure 5. Increase in Hsp25 with age and disease progression in G93A SOD-1 transgenic mice. A, Quantitation of Hsp25 on Western blots of spinal cord homogenates from wild-type and G93A SOD-1 mice. Ratios of Hsp25 to tubulin in samples from transgenic mice were normalized to ratios in matched samples of nontransgenic littermates. Note the threefold increase in $\mathrm{Hsp} 25$ in symptomatic G93A SOD-1 mice relative to those at $44 \mathrm{~d}$ of age. The mean $\mathrm{Hsp} 25$ level in the spinal cord of symptomatic animals was also higher than in samples from nonsymptomatic littermates. No inducible Hsp70 was detected on immunoblots (our unpublished data). Shown are means $\pm S D$ for three to nine animals per group. The asterisk indicates a significant difference from all other values; $p \leq 0.05$ ( $t$ test; one-tailed; unequal variance). $B$, Quantitation of $\alpha \mathrm{B}$-crystallin immunolabeling relative to tubulin on Western blots of lumbar spinal cord homogenates from 115-d-old G93A SOD-1 mice and age-matched nontransgenic littermates.

blots, which showed similar $\alpha \mathrm{B}$-crystallin levels among all groups (Fig. 5B).

The above findings in the B6SJL-TgN(SOD1-G93A)1Gur transgenic mouse line were confirmed in mice from the B6.Cg$\mathrm{TgN}(\mathrm{SOD} 1-\mathrm{G} 93 \mathrm{~A}){ }^{\mathrm{dl}}$ 1Gur lineage which exhibits slower disease progression (our unpublished data).

\section{Neither Hsp70 nor Hsp27 are upregulated in spinal cords from familial and sporadic ALS patients}

To determine whether the findings in transgenic mice could be extended to ALS patients, HSP expression was assessed by immunohistochemistry in the cervical spinal cord obtained at autopsy from patients with sporadic ALS (three cases), FALS (three cases, one of which harbored the A4V SOD-1 mutation), and two control cases. Motor neurons in sections of the cervical spinal cord obtained from ALS patients (Fig. $6 D$ ) were not labeled by anti-Hsp70. Glial immunoreactivity was occasionally observed in other parts of neuropil, indicating that this antibody can recognize Hsp70 when used for this procedure (our unpublished data).

Consistent with observations in transgenic mice, constitutive expression of the human Hsp27 isoform, equivalent to mouse Hsp25, was observed in motor neurons of control (Fig. 6A), sporadic ALS (Fig. $6 B$ ), and FALS (Fig. $6 C$ ) cases. However, unlike the G93A SOD-1 transgenic mice, high expression of Hsp27 in reactive astrocytes was not detected in spinal cords from either sporadic or FALS patients (Fig. 6C). Hsp27 immunoreactivity appeared localized to motor neuronal cell bodies and neurites rather than coincident with areas of reactive gliosis. Analysis of the background neuropil indicated that Hsp27 labeling (Fig. 6E) did not arise from morphologically typical astrocytes immunolabeled with anti-GFAP (Fig. 6F).

Thus, motor neurons of ALS patients failed to express Hsp70, consistent with findings in primary culture and transgenic mouse experimental models. However, the increase in $\mathrm{Hsp} 25$ in reactive 
astrocytes in G93A SOD-1 transgenic mice was not replicated in the spinal cord of patients with familial or sporadic ALS.

\section{Motor neurons expressed the major heat shock transcription factors HSF1 and HSF2}

To determine whether the failure of motor neurons to induce Hsp70 after heat shock, glutamate, or mutant SOD-1 expression was attributable to lack of HSF, expression of the two major mammalian HSFs, HSF1 and HSF2, was assessed in spinal cord cultures. HSF1 primarily controls transcriptional activation of HSP genes in response to environmental stress by binding to HSEs on HSP promoters as trimers and undergoing hyperphosphorylation (Morimoto, 1998). HSF2 has a high turnover rate because of proteasomemediated degradation (Mathew et al., 1998). When proteasome activity is inhibited sufficiently, HSF2 accumulates, forms trimers, translocates to the nucleus, and binds to HSEs, events associated with de novo transcription of HSP genes (Mathew et al., 1998).

In untreated spinal cord cultures, motor neurons and other cells were labeled by a monoclonal antibody to HSF1, which preferentially labeled nuclei (Fig. 7A). HSF2 was not detected in untreated cultures but accumulated in the nuclei of motor neurons and other spinal cord cells after overnight incubation with proteasome inhibitor MG132 (0.1-1 $\mu \mathrm{M})$ (Fig. 7B2) as reported previously in cell lines (Mathew et al., 1998). In addition to increasing levels of HSF2, MG132 induced strong expression of Hsp70 in motor neurons and other spinal cord cells (Fig. 7B4). Similar results were obtained with a more specific proteasome inhibitor, lactacystin (1-10 $\mu \mathrm{M}$; Calbiochem, La Jolla, CA) (our unpublished data). Hence, Hsp70 induction can occur in motor neurons under conditions of decreased proteasome activity or via downstream effects of proteasome inhibition.

\section{Activation of HSF1 caused strong induction of markers of the heat shock-stress response in motor neurons}

To address the possibility that motor neurons do not have sufficient amounts of HSF1 to mount a heat shock response, HSF $1^{\text {wt }}$ was overexpressed in motor neurons, and Hsp70 induction was assessed after heat stress. Motor neurons were microinjected with a plasmid-encoding $\mathrm{HSF} 1^{\mathrm{wt}}$, allowed to recover for $48 \mathrm{hr}$, and incubated at $42^{\circ} \mathrm{C}$ or $37^{\circ} \mathrm{C}$ for $1 \mathrm{hr}$ and then $2 \mathrm{hr}$ at $37^{\circ} \mathrm{C}$. These conditions of heat shock were the same as those used in experiments shown in Figure 2, but again, no increase in Hsp70 expression was detected before or after heat shock, despite clear overexpression of $\mathrm{HSF} 1^{\mathrm{wt}}$ in motor neurons (Fig. $8 A 1,5$ ). In contrast, robust $\mathrm{Hsp} 70$ expression was observed at $37^{\circ} \mathrm{C}$ in motor neurons injected with plasmid encoding a constitutively activated form of HSF1 $\left(\mathrm{HSF}^{(+)}\right.$) (Fig. 8A3,7) but not an inactivatable form $\left(\mathrm{HSF} 1^{(-)}\right.$) (Fig. $\left.8 A 4,8\right)$. HSF1 ${ }^{(+)}$has a deletion of amino acids 202-316, which changes the conformation of the protein rendering HSF1 constitutively active and eliminating the requirement for phosphorylation of serine residues in this region. HSF1 ${ }^{(-)}$has a deletion of amino acids 453-523 spanning the transcriptional
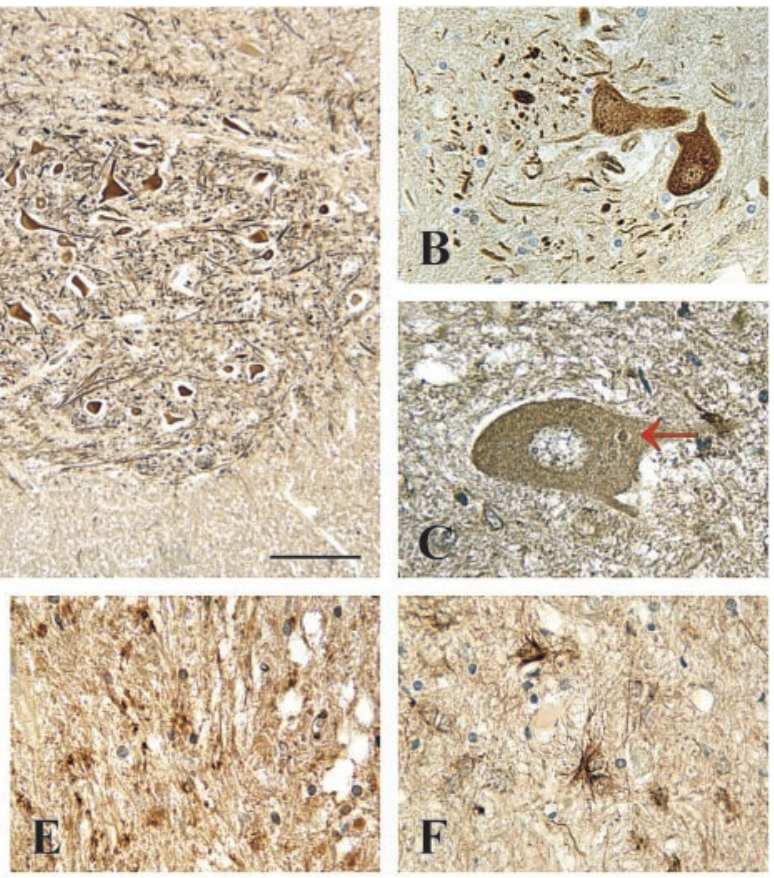

Figure 6. HSP expression in cervical spinal cord of control, sporadic, and FALS (A4V SOD-1 mutation). Hsp27 was detected in points to a spinal motor neuron containing a Bunina body. Hsp70 immunolabeling was not observed in the cytoplasm of moto neurons of FALS $(D)$ or sporadic ALS (our unpublished data). Hsp27 labeling in the neuropil ( $E$ ) does not correspond to the pattern of GFAP immunoreactivity ( $F$ ). Scale bars: $A, 100 \mu \mathrm{m} ; B, 40 \mu \mathrm{m} ; C-F, 20 \mu \mathrm{m}$.
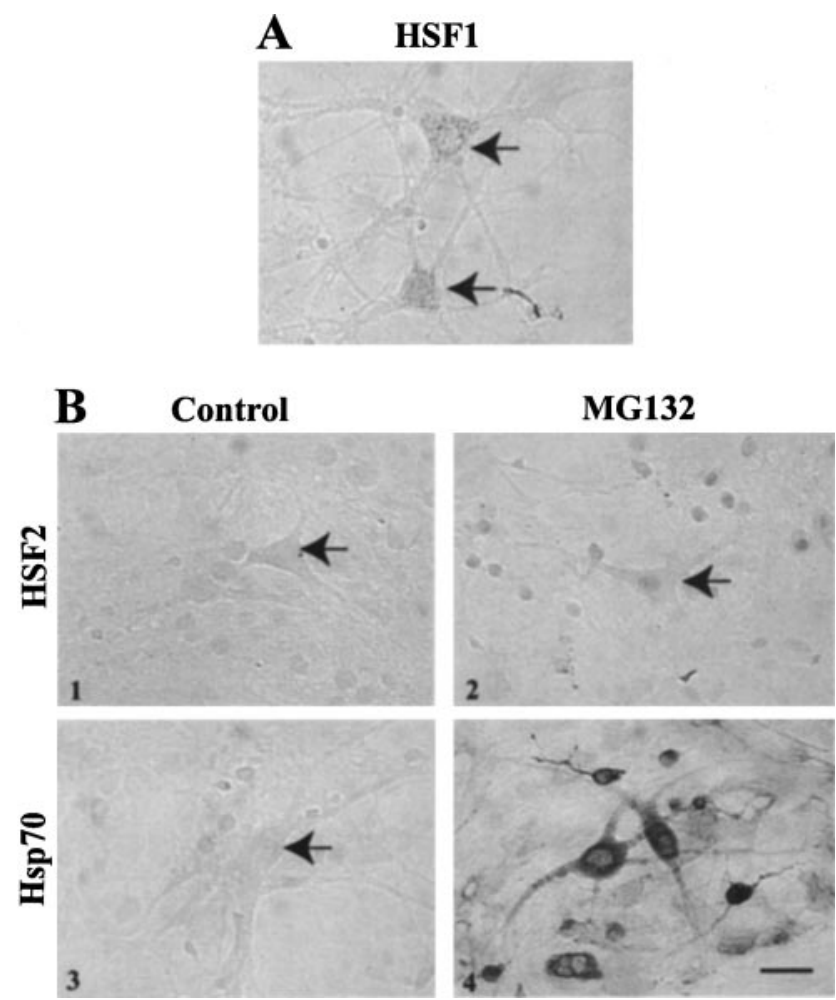

Figure 7. Motor neurons express the heat shock transcription factors HSF1 and HSF2. $A$, Motor neurons and other cells in primary spinal cord cultures were labeled by a monoclonal antibody to HSF1 (SPA-950). B, Overnight treatment with the proteasomal inhibitor MG132 (0.1 $\mu \mathrm{m})$ caused HSF2 to accumulate and translocate into the nuclei of spinal cord cells, including motor neurons (1,2). In motor neurons and other cells treated with MG132 (1 $\mu \mathrm{M})$, strong Hsp70 (SPA-810) expression was also detected by immunocytochemistry using DAB as substrate $(3,4)$. Arrows indicate motor neurons. Scale bar, $30 \mu \mathrm{m}$. 

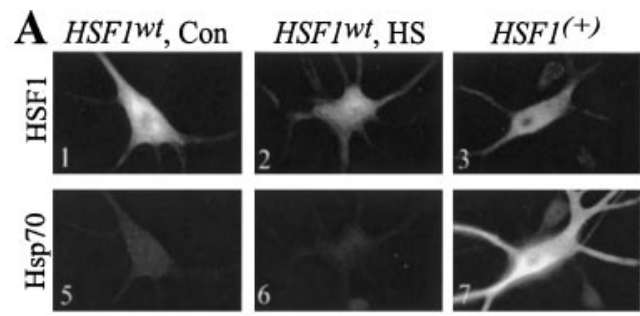

$\mathrm{HSFl}^{(-)}$
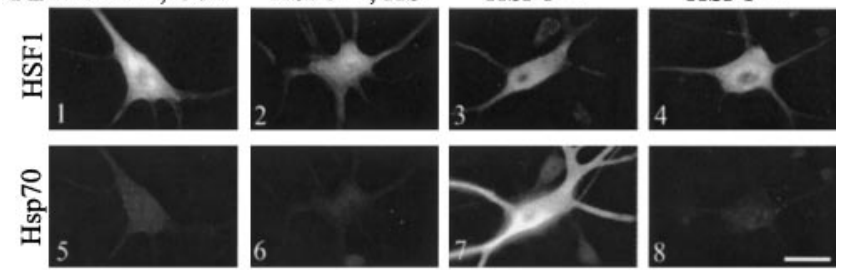

B

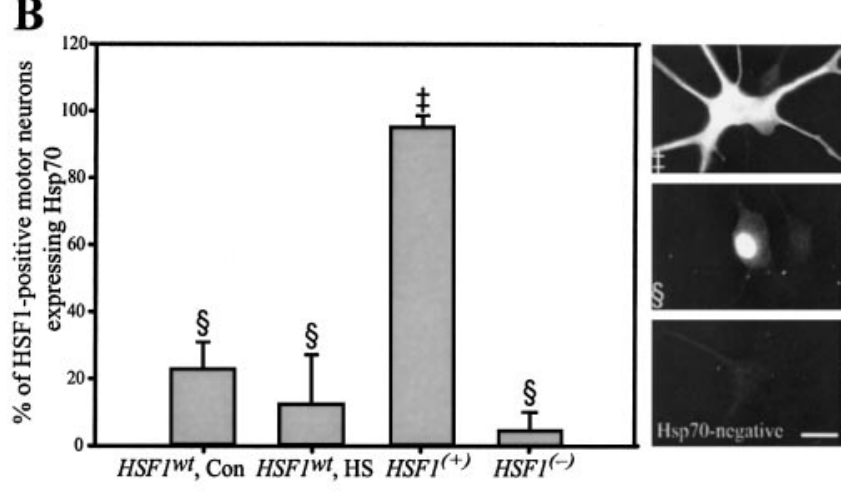

C

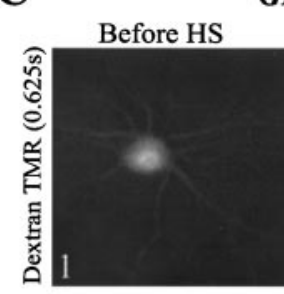

GFP
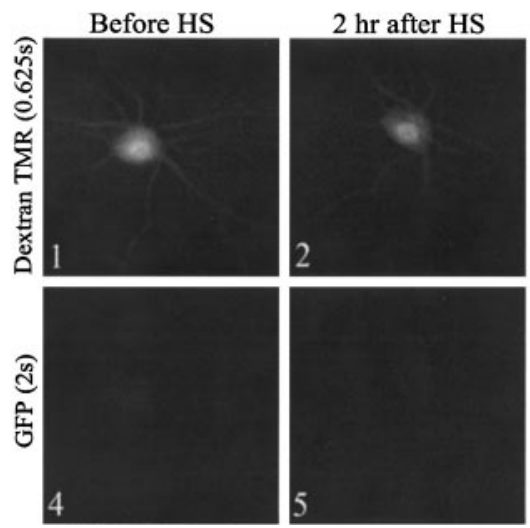

$G F P \& H S F 1^{(+)}$
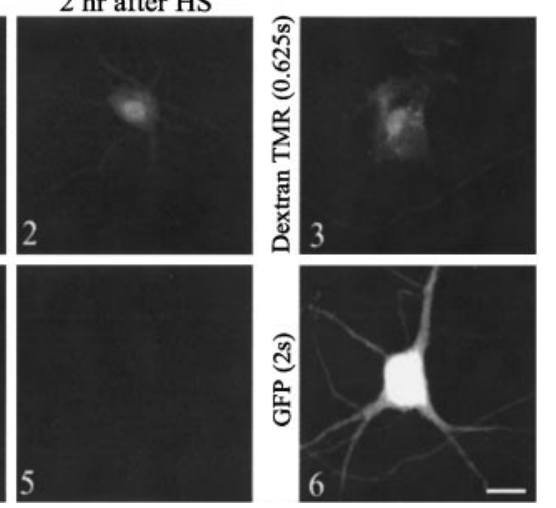

Figure 8. Expression of activated HSF1, but not HSF1 ${ }^{\text {wt }}$, by gene transfer induces HSP70 expression in motor neurons. $A, B$, Motor neurons were microinjected with plasmid expression vectors encoding HSF1 ${ }^{\text {wt }}$, constitutively activated HSF1 (HSF1 $\left.{ }^{(+)}\right)$, or nonactivatable HSF1 $\left(\mathrm{HSF} 1^{(-)}\right)$. After $48 \mathrm{hr}$, motor neurons injected with HSF1 ${ }^{\text {wt }}$ were heat shocked $\left(42^{\circ} \mathrm{C} ; 1 \mathrm{hr}\right)$ or subjected to control conditions $\left(37^{\circ} \mathrm{C} ; 1 \mathrm{hr}\right)$ and recovered at $37^{\circ} \mathrm{C}$ for $2 \mathrm{hr}$. All cultures were double labeled with antibodies against HSF1 and Hsp70. A, Although motor neurons expressed HSF1 $^{\text {wt }}(1,2)$ at levels comparable with HSF1 ${ }^{(+)}(3)$, only HSF1 ${ }^{(+)}$induced Hsp70 (5-7). B, Percentage of motor neurons coexpressing HSF1 and Hsp70 ( $n \geq 4$ cultures per group). Intense Hsp70 immunolabeling (‡) occurred only in motor neurons injected with $\mathrm{HSF}^{(+)}$. In the other three conditions, lower intensity labeling was observed frequently in the nucleus (§). Only $\mathrm{HSF}^{(+)}$significantly increased the percentage of motor neurons expressing Hsp70 ( $t$ test; one-tailed; unequal variance; $p<0.0001) . \mathrm{C}_{1} \mathrm{HSF}^{(+)}$also caused strong expression of a GFP reporter gene under the control of the Hsp70 promoter in motor neurons. Left, Motor neurons injected with the dextran TMR marker and GFP vector were imaged before and $2 \mathrm{hr}$ after heat shock. Right, Heat shock failed to induce GFP (5), in contrast to coexpression of $\mathrm{HSF}^{(+)}$, which resulted in strong GFP expression (6). Scale bar, $30 \mu \mathrm{m}$.

activation domain. Hsp70 induction in motor neurons injected with HSF $1^{(+)}$was consistently intense (Fig. $8 A 7, B$, top, $\ddagger$ ). In the occasional Hsp70-immunopositive motor neuron expressing $\mathrm{HSF} 1^{\text {wt }}$ or HSF $1^{(-)}$, labeling was of relatively low intensity and frequently localized to the nucleus (Fig. $8 \mathrm{~B}$, middle, $\$$ ). Not only did HSF1 ${ }^{(+)}$cause stronger expression of Hsp70 (Fig. 8A7), it also caused a significant increase in the number of cells that induced Hsp70 (Fig. 8 B).

Similar results were obtained using a GFP reporter gene driven by the human Hsp70 promoter (pEGFP-HSE-GFP). Motor neurons were coinjected with this vector along with the red fluorescent marker, $70 \mathrm{kDa}$ dextran TMR. The following day, motor neurons were imaged for TMR and GFP fluorescence (Fig. $8 \mathrm{C}$ ) before heat shock $\left(42^{\circ} \mathrm{C}, 1 \mathrm{hr}\right)$ and (in the same cells) after 2 , 10 , and $24 \mathrm{hr}$ recovery at $37^{\circ} \mathrm{C}$. GFP expression was never observed in motor neurons at any of the recovery times (Fig. 8C4,5). However, when $\mathrm{HSFl}^{(+)}$vector was coinjected with pEGFPHSE-GFP, strong induction of GFP was observed in motor neurons (Fig. 8C6). Thus, even with a high level of expression of wtHSF1, thermal stress failed to activate heat shock gene transcription, but bypassing the normal mechanisms of transcriptional activation resulted in expression of two different proteins under the control of the Hsp70 promoter.

\section{Discussion}

The results demonstrate that motor neurons have a high threshold for induction of the heat shock response. Although glia in primary spinal cord cultures upregulated the major stressinducible protein Hsp70, after heat shock, motor neurons failed to express Hsp70 when subjected to hyperthermia, glutamate excitotoxicity, or expression of mutant SOD-1. Also, cultured motor neurons microinjected with a GFP reporter gene driven by the Hsp70 promoter failed to induce GFP after heat shock. No induction of Hsp70 was observed in spinal motor neurons in two lines of G93A mutant SOD-1 transgenic mice or in patients with ALS.

Because different stressors can induce expression of different HSPs, Hsp 25 and $\alpha \mathrm{B}$-crystallin were also monitored. Although endogenous expression of both proteins was detected in the cytoplasm of motor neurons in culture and in vivo, no qualitative differences were observed after stress treatments in culture, G93A SOD-1 transgenic mice throughout the disease course, or ALS spinal cords. Recently, increased Hsp25 was reported in nuclei of motor neurons in G93A SOD-1 transgenic mice (Vleminckx et al., 2002). This was not observed in the present study, although mice were killed at an earlier stage of clinical disease. Consistent with the findings of Vleminckx et al. (2002), Hsp25 and, to a lesser extent, $\alpha \mathrm{B}$-crystallin were increased in spinal cord homogenates of G93A SOD-1 mice in parallel with disease progression. By immunohistochemistry, increased Hsp25 was particularly evident in reactive astrocytes, which may represent a common event during reactive astrocytosis or a stress response to mutant SOD-1 toxicity. Studies in other rodent models of injury and human disease have demonstrated increased astrocytic Hsp25 (Manzerra and Brown, 1992; Shinohara et al., 1993; Renkawek et al., 1994; Satoh and Kim, 1995; Marcuccilli et al., 1996; Krueger et al., 1999; Mautes and Noble, 2000). However, the significance of astrocytic Hsp25 to ALS is questioned because upregulation of the human homolog Hsp27 was not observed in the spinal cord of ALS patients, despite demonstration of gliosis by GFAP immunolabeling. Whether the difference is related to species, the HSPs investigated, specific toxicity of the G93A SOD-1 mutation, and disease pathogenesis in mouse models versus human patients remains to be determined.

Neurons, in general, show a higher threshold for induction of the stress response than astrocytes; yet, evidence points to motor neurons having a particularly high threshold for induction of Hsp70. DRG sensory neurons and other neurons in spinal cordDRG culture expressed Hsp70 after heat shock at temperatures 
$>42^{\circ} \mathrm{C}$ but motor neurons did not (our unpublished data). Other studies have shown that spinal motor neurons in situ failed to induce Hsp70 after heat shock (Manzerra and Brown, 1992; Brown and Rush, 1999) and spinal cord contusion (Mautes and Noble, 2000) in contrast with other types of neurons, such as cerebellar, cortical, and pyramidal, which upregulated Hsp70 after heat shock (Lowenstein et al., 1991; Bechtold et al., 2000) and in different ischemic paradigms (Krueger et al., 1999; Currie et al., 2000). Although sciatic nerve axotomy increased Hsp25 in adult rat motor neurons (Costigan et al., 1998; Benn et al., 2002), in transgenic models of motor neuron disease, Hsp25 appeared unchanged (in the present study), was increased in nuclei (Vleminckx et al., 2002), or decreased (Pieri et al., 2001).

Exposure of motor neurons to hyperthermia would be expected to activate heat shock gene expression primarily through HSF1 (Morimoto, 1998). Inactive HSF1 can be found: (1) as a monomer in the cytoplasm, forming transient associations with Hsp70 and Hsp90 (Morimoto and Santoro, 1998), and (2) in nuclear granules (Cotto et al., 1997; Jolly et al., 2002). When levels of HSPs are insufficient in stressed cells, HSF1 trimerizes, binds to HSEs, and undergoes phosphorylation at multiple sites. This changes its conformation, recruiting the transcriptional machinery at HSP promoters and culminating in transactivation of heat shock genes (Morimoto and Santoro, 1998; Holmberg et al., 2001). Thus, arrest of HSP induction in motor neurons could occur at the level of HSF1 expression, trimerization of the transcription factor, binding to HSEs, phosphorylation-activation of HSF1, or HSP mRNA stability, processing, and/or translation.

The failure of hippocampal neurons to induce Hsp70 after heat shock was attributed to a lack of HSF1 (Marcuccilli et al., 1996). Motor neurons did express HSF1, but it was still possible that they did not express sufficient levels to mount a heat shock response or that immunolabeling did not reflect the true state. However, when the level of HSF $1^{\text {wt }}$ was increased in motor neurons, heat shock still failed to induce Hsp70. This experiment demonstrated that the block in stress-induced expression of Hsp70 in motor neurons was not at the level of HSF1 expression.

Previous studies had implicated faster disassembly of hyperphosphorylated HSF1 trimers in the failure of Scrapie to induce Hsp70 in ScN2a neuroblastoma cells (Winklhofer et al., 2001), and the inability of HSF1 to bind to the Hsp70 promoter in the reduced ability of retinoblastoma Y79 cells to transcribe Hsp70 after heat shock (Mathur et al., 1994). However, a constitutively active form of $\mathrm{HSF} 1, \mathrm{HSF}_{1}{ }^{(+)}$, but not the inactivatable form, $\mathrm{HSF}^{(-)}$, induced strong Hsp70 when expressed in cultured motor neurons. For HSF1 ${ }^{(+)}$to have transactivated gene expression, trimerization, nuclear transport, and binding to HSE must have occurred. Although this could not be assessed directly in single cells of dissociated spinal cord cultures, it has been demonstrated in cell lines that $\mathrm{HSF}_{1}{ }^{\mathrm{wt}}, \mathrm{HSF} 1^{(+)}$, and $\mathrm{HSF}^{(-)}{ }^{(-)}$oligomerize and bind to HSEs, but only HSF $1^{(+)}$causes transactivation of HSP genes in the absence of stress. Heat shock was required for HSF ${ }^{\text {wt }}$ to transactivate HSP gene expression (Zuo et al., 1995).

In addition to Hsp70, HSF $1^{(+)}$induced expression of a GFP reporter under the control of the Hsp70 promoter. This result and the increase in Hsp70 after HSF1 ${ }^{(+)}$gene transfer indicate that once the HSF-HSE complex was activated, transcription and translation proceeded.

The most likely cause of the failure of motor neurons to induce a stress response involves alterations in the signaling pathways that regulate HSF1 activation. HSF $1^{(+)}$has a deletion spanning amino acids 202-316, a region harboring numerous serine residues, the phosphorylation states of which regulate the trans- activational competence of HSF1 by altering its conformation (Zuo et al., 1995). Deletion of this domain changes the conformation of HSF1, rendering it constitutively active and obviating the requirement for phosphorylation. Within this region, constitutive phosphorylation at serines 303 and 307 by glycogen synthase kinase $3 \beta$ and extracellular signal-regulated kinase (Chu et al., 1996) represses transcriptional activity of HSF1, implicating dephosphorylation at these sites in HSF1 activation. Stressinducible phosphorylation of another residue within this domain, serine 230, which lies within a consensus site for calciumcalmodulin kinase II, is a key phosphorylation event resulting in HSF1 activation (Holmberg et al., 2001). Lack of activation or changes in the regulation of these candidate kinases could be responsible for the deficiency in the heat shock-stress response observed in motor neurons.

In contrast to heat shock, glutamate excitotoxicity, and expression of mutant SOD-1, peptide inhibitors of proteasome activity induced robust expression of Hsp70 in motor neurons concomitant with accumulation and nuclear localization of the transcription factor HSF2. This result is consistent with the role for HSF2 in HSP gene transcription (Mathew et al., 1998). Proteasome inhibition has been implicated in disorders characterized by protein aggregation, including trinucleotide repeat diseases (Bence et al., 2001; Sherman and Goldberg, 2001). Mutant SOD-1 also undergoes degradation in proteasomes (Hoffman et al., 1996; Johnston et al., 2000), and recent studies demonstrated decreased proteasome activity in cell lines expressing mutant SOD-1 (Hyun et al., 2002; Urushitani et al., 2002) and lumbar spinal cord from G93A SOD-1 transgenic mice (our unpublished data). Low levels of HSF2 are maintained by proteasomal degradation (see Results). If mutant SOD-1 had abrogated proteasome function, accumulation of HSF2 and transactivation of $H s p 70$ would be expected, but neither was observed in cultured motor neurons expressing G93A SOD-1 (our unpublished data) (Table 1) nor in motor neurons in lumbar spinal cord of G93A mice (our unpublished data) (Fig. 5A-C). However, neither the threshold level of proteasome inhibition required for HSF2 accumulation nor the requirement of other factors, such as the HSF2 modulator, SUMO-1 (Goodson et al., 2001), are known. Proteasome inhibition also increases HSF1 activation, presumably by reduced proteolysis of HSF1-targeting kinase(s) (Holmberg et al., 2001). The level of proteasome inhibition by mutant SOD-1 may not be sufficient to induce Hsp70 via either HSF2 accumulation or HSF1 activation.

In conclusion, our results indicate that the impaired ability of motor neurons to mount a heat shock-stress response occurs at the level of activation of HSF1, the major cellular stress sensor. This feature, in addition to other factors, such as neurofilament organization, high level of glutamatergic input, expression of calcium-permeable AMPA receptors, and low levels of free radical scavengers and cytosolic calcium-binding proteins (for review, see Roy et al., 1998), may contribute to their preferential vulnerability to disease. Preliminary studies indicate that expression of constitutively activated HSF1 protects motor neurons from mutant SOD-1 toxicity (our unpublished data), supporting the possibility that pharmacological activation of HSF1 in motor neurons may overcome the deleterious effects of other diseaserelated and environmental stresses.

\section{References}

Bechtold DA, Rush SJ, Brown IR (2000) Localization of the heat-shock protein Hsp70 to the synapse following hyperthermic stress in the brain. J Neurochem 74:641-646. 
Bence NF, Sampat RM, Kopito RR (2001) Impairment of the ubiquitinproteasome system by protein aggregation. Science 292:1552-1555.

Benn SC, Perrelet D, Kato AC, Scholz J, Decosterd I, Mannion RJ, Bakowska JC, Woolf CJ (2002) Hsp27 upregulation and phosphorylation is required for injured sensory and motor neuron survival. Neuron 36:45-56.

Brown IR, Rush SJ (1999) Cellular localization of the heat shock transcription factors HSF1 and HSF2 in the rat brain during postnatal development and following hyperthermia. Brain Res 821:333-340.

Bruening W, Roy J, Giasson B, Figlewicz DA, Mushynski WE, Durham HD (1999) Up-regulation of protein chaperones preserves viability of cells expressing toxic $\mathrm{Cu} / \mathrm{Zn}$-superoxide dismutase mutants associated with amyotrophic lateral sclerosis. J Neurochem 72:693-699.

Bruijn LI, Becher MW, Lee MK, Anderson KL, Jenkins NA, Copeland NG, Sisodia SS, Rothstein JD, Borchelt DR, Price DL, Cleveland DW (1997) ALS-linked SOD1 mutant G85R mediates damage to astrocytes and promotes rapidly progressive disease with SOD1-containing inclusions. Neuron 18:327-338.

Chiu AY, Zhai P, Dal Canto MC, Peters TM, Kwon YW, Prattis SM, Gurney ME (1995) Age-dependent penetrance of disease in a transgenic mouse model of familial amyotrophic lateral sclerosis. Mol Cell Neurosci $6: 349-362$.

Chu B, Soncin F, Price BD, Stevenson MA, Calderwood SK (1996) Sequential phosphorylation by mitogen-activated protein kinase and glycogen synthase kinase 3 represses transcriptional activation by heat shock factor-1. J Biol Chem 271:30847-30857.

Cleveland DW, Rothstein JD (2001) From Charcot to Lou Gehrig: deciphering selective motor neuron death in ALS. Nat Rev Neurosci $2: 806-819$.

Costigan M, Mannion RJ, Kendall G, Lewis SE, Campagna JA, Coggeshall RE, Meridith-Middleton J, Tate S, Woolf CJ (1998) Heat shock protein 27: developmental regulation and expression after peripheral nerve injury. J Neurosci 18:5891-5900.

Cotto J, Fox S, Morimoto R (1997) HSF1 granules: a novel stress-induced nuclear compartment of human cells. J Cell Sci 110:2925-2934.

Currie RW, Ellison JA, White RF, Feuerstein GZ, Wang X, Barone FC (2000) Benign focal ischemic preconditioning induces neuronal Hsp70 and prolonged astrogliosis with expression of Hsp27. Brain Res 863:169-181.

Dal Canto MC, Gurney ME (1994) Development of central nervous system pathology in a murine transgenic model of human amyotrophic lateral sclerosis. Am J Pathol 145:1271-1279.

Dal Canto MC, Gurney ME (1995) Neuropathological changes in two lines of mice carrying a transgene for mutant human $\mathrm{Cu}, \mathrm{Zn} \mathrm{SOD}$, and in mice overexpressing wild type human SOD: a model of familial amyotrophic lateral sclerosis (FALS). Brain Res 676:25-40.

Deng H-X, Hentati A, Tainer JA, Iqbal Z, Cayabyab A, Hung W-Y, Getzoff ED, Hu P, Herzfeldt B, Roos RP, Warner C, Deng G, Soriano E, Smyth C, Parge HE, Ahmed A, Roses AD, Hallewell RA, Pericak-Vance MA, Siddique T (1993) Amyotrophic lateral sclerosis and structural defects in $\mathrm{Cu}, \mathrm{Zn}$ Superoxide dismutase. Science 261:1047-1051.

Doroudchi MM, Minotti S, Figlewicz DA, Durham HD (2001) Nitrotyrosination contributes minimally to toxicity of mutant SOD1 associated with ALS. NeuroReport 12:1239-1243.

Durham HD, Roy J, Dong L, Figlewicz DA (1997) Aggregation of mutant $\mathrm{Cu} / \mathrm{Zn}$ superoxide dismutase proteins in a culture model of ALS. J Neuropathol Exp Neurol 56:523-530.

Fink SL, Chang LK, Ho DY, Sapolsky RM (1997) Defective herpes simplex virus vectors expressing the rat brain stress-inducible heat shock protein 72 protect cultured neurons from severe heat shock. J Neurochem 68:961-969.

Gabai VL, Meriin AB, Mosser DD, Caron AW, Rits S, Shifrin VI, Sherman MY (1997) Hsp70 prevents activation of stress kinases. A novel pathway of cellular thermotolerance. J Biol Chem 272:18033-18037.

Goodson ML, Hong Y, Rogers R, Matunis MJ, Park-Sarge OK, Sarge KD (2001) Sumo-1 modification regulates the DNA binding activity of heat shock transcription factor 2, a promyelocytic leukemia nuclear body associated transcription factor. J Biol Chem 276:18513-18518.

Hall ED, Oostveen JA, Gurney ME (1998) Relationship of microglial and astrocytic activation to disease onset and progression in a transgenic model of familial ALS. Glia 23:249-256.

Hoffman EK, Wilcox HM, Scott RW, Siman R (1996) Proteasome inhibition enhances the stability of mouse $\mathrm{Cu} / \mathrm{Zn}$ superoxide dismutase with mutations linked to familial amyotrophic lateral sclerosis. J Neurol Sci 139:15-20.

Holmberg CI, Hietakangas V, Mikhailov A, Rantanen JO, Kallio M, Meinander A, Hellman J, Morrice N, MacKintosh C, Morimoto RI, Eriksson JE, Sistonen L (2001) Phosphorylation of serine 230 promotes inducible transcriptional activity of heat shock factor 1. EMBO J 20:3800-3810.

Hyun DH, Lee MH, Halliwell B, Jenner P (2002) Proteasomal dysfunction induced by 4-hydroxy-2, 3-trans-nonenal, an end-product of lipid peroxidation: a mechanism contributing to neurodegeneration? J Neurochem 83:360-370.

Johnston JA, Dalton MJ, Gurney ME, Kopito RR (2000) Formation of high molecular weight complexes of mutant $\mathrm{Cu}, \mathrm{Zn}$-superoxide dismutase in a mouse model for familial amyotrophic lateral sclerosis. Proc Natl Acad Sci USA 97:12571-12576.

Jolly C, Konecny L, Grady DL, Kutskova YA, Cotto JJ, Morimoto RI, Vourc'h C (2002) In vivo binding of active heat shock transcription factor 1 to human chromosome 9 heterochromatin during stress. J Cell Biol 156:775-781.

Kong J, Xu Z (1998) Massive mitochondrial degeneration in motor neurons triggers the onset of amyotrophic lateral sclerosis in mice expressing a mutant SOD1. J Neurosci 18:3241-3250.

Krueger AM, Armstrong JN, Plumier J, Robertson HA, Currie RW (1999) Cell specific expression of Hsp70 in neurons and glia of the rat hippocampus after hyperthermia and kainic acid-induced seizure activity. Brain Res Mol Brain Res 71:265-278.

Lowenstein DH, Chan PH, Miles MF (1991) The stress protein response in cultured neurons: characterization and evidence for a protective role in excitotoxicity. Neuron 7:1053-1060.

Ludolph AC, Meyer T, Riepe MW (2000) The role of excitotoxicity in ALSwhat is the evidence? J Neurol 247:7-16.

Manzerra P, Brown IR (1992) Expression of heat shock genes (hsp70) in the rabbit spinal cord: localization of constitutive and hyperthermiainducible mRNA species. J Neurosci Res 31:606-615.

Marcuccilli CJ, Mathur SK, Morimoto RI, Miller RJ (1996) Regulatory differences in the stress response of hippocampal neurons and glial cells after heat shock. J Neurosci 16:478-485.

Mathew A, Mathur SK, Morimoto RI (1998) Heat shock response and protein degradation: regulation of HSF2 by the ubiquitin-proteasome pathway. Mol Cell Biol 18:5091-5098.

Mathur SK, Sistonen L, Brown IR, Murphy SP, Sarge KD, Morimoto RI (1994) Deficient induction of human hsp70 heat shock gene transcription in Y79 retinoblastoma cells despite activation of heat shock factor 1. Proc Natl Acad Sci USA 91:8695-8699.

Mautes AE, Noble LJ (2000) Co-induction of HSP70 and heme oxygenase-1 in macrophages and glia after spinal cord contusion in the rat. Brain Res 883:233-237.

Meriin AB, Yaglom JA, Gabai VL, Zon L, Ganiatsas S, Mosser DD, Zon L, Sherman MY (1999) Protein-damaging stresses activate c-Jun N-terminal kinase via inhibition of its dephosphorylation: a novel pathway controlled by HSP72. Mol Cell Biol 19:2547-2555.

Min JN, Han MY, Lee SS, Kim KJ, Park YM (2000) Regulation of rat heat shock factor 2 expression during the early organogenic phase of embryogenesis. Biochim Biophys Acta 1494:256-262.

Morimoto RI (1998) Regulation of the heat shock transcriptional response: cross talk between a family of heat shock factors, molecular chaperones, and negative regulators [Rev]. Genes Dev 12:3788-3796.

Morimoto RI, Santoro MG (1998) Stress-inducible responses and heat shock proteins: new pharmacologic targets for cytoprotection. Nat Biotechnol 16:833-838.

Morimoto RI, Kline MP, Bimston DN, Cotto JJ (1997) The heat-shock response: regulation and function of heat-shock proteins and molecular chaperones. Essays Biochem 32:17-29.

Pieri I, Cifuentes-Diaz C, Oudinet JP, Blondet B, Rieger F, Gonin S, Arrigo AP, Thomas Y (2001) Modulation of HSP25 expression during anterior horn motor neuron degeneration in the paralyse mouse mutant. J Neurosci Res 65:247-253.

Plumier JC, Hopkins DA, Robertson HA, Currie RW (1997) Constitutive expression of the $27-\mathrm{kDa}$ heat shock protein (Hsp27) in sensory and motor neurons of the rat nervous system. J Comp Neurol 384:409-428.

Renkawek K, Voorter CE, Bosman GJ, van Workum FP, de Jong WW (1994) Expression of alpha B-crystallin in Alzheimer's disease. Acta Neuropathol (Berl) 87:155-160. 
Rordorf G, Koroshetz WJ, Bonventre JV (1991) Heat shock protects cultured neurons from glutamate toxicity. Neuron 7:1043-1051.

Rosen DR, Siddique T, Patterson D, Figlewicz DA, Sapp P, Hentati A, Donaldson D, Goto J, O’Regan JP, Deng HX (1993) Mutations in Cu/Zn superoxide dismutase gene are associated with familial amyotrophic lateral sclerosis. Nature 362:59-62.

Rothstein JD, Van Kammen M, Levey AI, Martin LJ, Kuncl RW (1995) Selective loss of glial glutamate transporter GLT-1 in amyotrophic lateral sclerosis. Ann Neurol 38:73-84.

Roy J, Minotti S, Dong L, Figlewicz DA, Durham HD (1998) Glutamate potentiates the toxicity of mutant $\mathrm{Cu} / \mathrm{Zn}$-superoxide dismutase in motor neurons by postsynaptic calcium-dependent mechanisms. J Neurosci 18:9673-9684.

Sato K, Matsuki N (2002) A $72 \mathrm{kDa}$ heat shock protein is protective against the selective vulnerability of CA1 neurons and is essential for the tolerance exhibited by CA3 neurons in the hippocampus. Neuroscience 109:745-756

Satoh JI, Kim SU (1995) Differential expression of heat shock protein HSP27 in human neurons and glial cells in culture. J Neurosci Res 41:805-818.

Sherman MY, Goldberg AL (2001) Cellular defenses against unfolded proteins: a cell biologist thinks about neurodegenerative diseases. Neuron 29:15-32.

Shinder GA, Lacourse MC, Minotti S, Durham HD (2001) Mutant Cu/Znsuperoxide dismutase proteins have altered solubility and interact with heat shock/stress proteins in models of amyotrophic lateral sclerosis. J Biol Chem 276:12791-12796.

Shinohara H, Inaguma Y, Goto S, Inagaki T, Kato K (1993) Alpha B crystallin and HSP28 are enhanced in the cerebral cortex of patients with Alzheimer's disease. J Neurol Sci 119:203-208.

Snider BJ, Choi DW (1996) Heat stress reduces glutamate toxicity in cultured neurons without hsp70 expression. Brain Res 729:273-276.

Uney JB, Kew JN, Staley K, Tyers P, Sofroniew MV (1993) Transfectionmediated expression of human Hsp70i protects rat dorsal root ganglian neurones and glia from severe heat stress. FEBS Lett 334:313-316.

Urushitani M, Kurisu J, Tsukita K, Takahashi R (2002) Proteasomal inhibition by misfolded mutant superoxide dismutase 1 induces selective motor neuron death in familial amyotrophic lateral sclerosis. J Neurochem 83:1030-1042.

Vleminckx V, Van Damme P, Goffin K, Delye H, Van Den BL, Robberecht W (2002) Upregulation of HSP27 in a transgenic model of ALS. J Neuropathol Exp Neurol 61:968-974.

Winklhofer KF, Reintjes A, Hoener MC, Voellmy R, Tatzelt J (2001) Geldanamycin restores a defective heat shock response in vivo. J Biol Chem 276:45160-45167.

Yenari MA, Fink SL, Sun GH, Chang LK, Patel MK, Kunis DM, Onley D, Ho DY, Sapolsky RM, Steinberg GK (1998) Gene therapy with HSP72 is neuroprotective in rat models of stroke and epilepsy. Ann Neurol 44:584-591.

Zuo J, Rungger D, Voellmy R (1995) Multiple layers of regulation of human heat shock transcription factor 1. Mol Cell Biol 15:4319-4330. 